\title{
Guerra dos mascates: crônica dos tempos coloniais, de Alencar: um antimodelo do romance histórico oitocentista
}

Guerra dos mascates, by Alencar:

an antimodel of the eighteenth century historical novel

MARILENE WeINHARdT ${ }^{1}$

Resumo: 0 romance $A$ guerra dos mascates, publicado por José de Alencar em dois volumes (1873-74), foi tratado pela crítica contemporânea do autor como roman à clé e consta na historiografia literária como obra menor. No entanto, se lido sem usar o modelo do romance histórico romântico como paradigma, a percepção é outra. A proposta desta leitura consiste em apreender os elementos de comédia presentes na narrativa e alguns procedimentos frequentes na ficção histórica do final do século XX.

Palavras-Chaves: Romance histórico; José de Alencar; Guerra dos mascates; ficção romântica.

\begin{abstract}
The novel A guerra dos mascates, published by José de Alencar in two volumes (1873-1874), was considered by the author's contemporaneous critics as roman à clé and is included in the literary historiography as a minor work. Nonetheless, if read without taking the romantic historical novel as a paradigm, the perception is different. This reading proposes to apprehend the elements of comedy that appear in the narrative, as well as some common procedures in late-nineteenth century historical fiction.
\end{abstract}

Keywords: Historical novel; José de Alencar; Guerra dos mascates; romantic fiction.

${ }^{1}$ Universidade Federal do Paraná (UFPR); CNPq. 
A relevância de José de Alencar na História da Literatura Brasileira do século XIX é fato inconteste. Historiadores e críticos da literatura podem ser mais ou menos enfáticos na apreciação do escritor, mas ninguém o ignora, sobretudo quanto à produção romanesca. Como sabemos, seguiu sendas abertas por predecessores, como Joaquim Manuel de Macedo e Manuel Antonio de Almeida, nos romances de costumes e urbanos, e desbravou outras, como o romance indianista. O próprio escritor facilitou a tarefa dos historiadores, no bem conhecido prefácio intitulado «Benção paterna», constante no romance Sonhos d'ouro (1872). Quanto à ficção histórica, se não é exatamente o primeiro escritor brasileiro a praticá-la, certamente deu-lhe foros de cidadania estética no cenário nacional. Sobre essa categoria romanesca, no referido prefácio consta:

O segundo período é histórico: representa o consórcio do povo invasor com a terra americana, que dele recebia a cultura, e the retribuía nos eflúvios de sua natureza virgem e nas reverberações de um solo esplêndido.

É da gestação lenta do povo americano, que devia sair da estirpe lusa, para continuar no novo mundo as gloriosas tradições de seu progenitor. Esse período colonial terminou com a independência.

A ele pertencem $O$ guarani e as Minas de Prata. Há aí muita e boa messe a colher para nosso romance histórico [...]. (Alencar, s. d.: 17)

Não há que estranhar a ausência da narrativa Guerra dos mascates, tomando-a como índice de obra renegada ou algo semelhante, uma vez que só viria a ser publicada no ano seguinte. De qualquer forma, certamente não cabe no padrão aí delineado.

A crítica, seja sugestionada pela classificação proposta pelo próprio Alencar, seja pelas dificuldades para interpretá-lo, seja por considerá-lo efetivamente obra menor, pouca atenção dispensou a esse romance, quando não o ignorou. Restrinjo-me a citar três manuais, sem correr grande risco de anacronismo. Os projetos abrangentes de História da Literatura Brasileira posteriores ao Modernismo datam das duas décadas iniciais da segunda metade do século passado. Na Formação da literatura brasileira (1957), entre as muitas páginas dedicadas a Alencar, Antonio Candido avalia:

A Guerra dos Mascates, (1870) é um romance histórico cheio de alusões à política do Império, muito mais cuidado documentariamente, muito mais «arranjado» como composição que As minas de pratai; mas não tem a sua inspiração e vigor narrativo». (Candido, 1975: 222)

Em O romantismo (1967), de Soares Amora, ainda que Alencar seja contemplado com um subcapítulo de quatro dezenas de páginas, o título é apenas citado. Convém observar que O guarani é analisado em função de quatro «fórmulas» do romance histórico romântico, buscadas nos modelos europeus. Adianto que, nesta leitura, apreende-se como singular no 
título Guerra dos mascates justamente a superação dessas fórmulas, ou sua transformação, seu revés. A conclusão do historiador segue outro percurso, considerando que à Guerra dos mascates e às narrativas reunidas no título Alfarrábios «faltava, a seus temas, a essência poética e a larga e profunda significação nacional que possuía a Casa do Paquequer, e consequentemente faltou ao artista, na sua elaboração, a força do entusiasmo e da sensibilidade poética» (Amora, 1973: 264). É bem verdade que As minas de prata também não recebe grande atenção de Soares Amora.

Em História concisa da Literatura Brasileira (1970), Alfredo Bosi recorre a longa citação de «Como e por que sou romancista» para concluir:

\footnotetext{
[...] importava a Alencar cobrir com a sua obra narrativa passado e presente, cidade e campo, litoral e sertão, e compor uma espécie de suma romanesca do Brasil. Entretanto, mais do que repetir a partição por assuntos dos seus vinte e um romances, em indianistas, históricos, regionais e citadinos, conviria buscar o motivo unitário que rege a sua estrutura, e que, talvez, se possa enunciar como um anseio profundo de evasão no tempo e no espaço animado por um egotismo radical. Traços ambos visceralmente românticos. (Bosi, 1975: 151)
}

A apreciação da obra alencariana é pautada por essa busca do referido «motivo unitário» que rege a estrutura, concluindo que Alencar tem uma visão eufórica da história brasileira. Guerra dos mascates certamente não referenda esse esquema, antes comporta visão disfórica. Só pode ser posto à margem, sob pena de contradizer a proposta de interpretação.

Uma arguta estudiosa de Alencar, Valéria De Marco, põe em xeque essas leituras que minoram, quando não desprezam, o romance Guerra dos mascates. Em A perda das ilusões, o romance histórico de José de Alencar (1993), nos deparamos com análise pormenorizada de Iracema, As minas de prata e Guerra dos mascates, sem favoritismo, sem parti-pris. Recorrendo a Northrop Frye como esteira teórica, Valéria De Marco constrói o percurso da ficção histórica alencariana orientada pela seguinte premissa: «Tem ele [Frye] a concepção de que a tradição literária descreve um percurso de descenso na escala dos modos de ficção, partindo do mito, passando pelo romanesco, imitativo alto, imitativo baixo para chegar ao irônico e aí retornar» (Marco, 1993: 17). Via de regra, esse princípio é usado para abordar, ou explicar, uma linhagem longa, quando não todo o percurso de uma literatura nacional. A singularidade do uso feito pela estudiosa é a aplicação desse roteiro, com ajustes, é verdade, no interior da produção de um único autor, mais especificamente, de uma das tantas modalidades romanescas produzidas por Alencar. $O$ resultado é o entendimento de $O$ guarani como «uma estória romanesca que caminha para o mito», enquanto As minas de prata caracteriza-se como «um exemplar romanesco de procura de tesouros que reserva para o final alguns respingos das tintas do prosaico» 
e, finalmente, em a Guerra dos mascates, «a ilusão romanesca mostra-se duramente ferida pela sátira» (Marco, 1993: 17-18).

A leitura aqui apresentada é tributária à de Valéria De Marco. No entanto, há diferença de inscrição. Em A perda das ilusões, o limite, portanto o termo de comparação, é a produção de Alencar. Assim, a explicação para a singularidade de Guerra dos mascates reside no momento vivido pelo autor, desencantado com a política, ressentido com o poder, especialmente com o imperador, que preterira seu nome para uma cadeira no senado. Redimensionar essa mesma interpretação, inscrevendo Guerra dos mascates como sátira no panorama do romance histórico brasileiro pode produzir uma brecha no modo como costumamos tratar esse percurso.

Antes de entrar na leitura do romance propriamente, convém examinar alguns registros do evento histórico. Em História do Brasil. Uma interpretação (2008), de Adriana Lopez e Carlos Guilherme Mota, no capítulo intitulado «Conflitos e rebeliões coloniais», analisando a situação econômico-comercial no «período que se seguiu à restauração (1640) e à expulsão dos invasores holandeses (1654)», consta:

Em Pernambuco, os comerciantes judeus e holandeses foram substituídos por comerciantes da Metrópole, cujos interesses estavam estreitamente ligados aos da Coroa.

A crise financeira obrigou a Coroa a tomar uma série de medidas visando centralizar a administração de sua colônia americana. Nesse processo, as elites locais, sobretudo as das áreas afetadas pela ocupação holandesa, perderam poder político. (Lopez e Mota, 2008: 178)

0 item «Conflitos internos na colônia» traz quatro subitens. À Guerra dos mascates é dedicado o último:

A crise econômica resultante do fim da ocupação holandesa no Nordeste provocou uma série de atritos entre os governadores e os colonos dessa região. [...]

À medida que o século chegava ao fim, agravava-se a tensão entre os comerciantes portugueses residentes em Recife e os produtores luso-brasileiros. Esse atrito assumiu a forma de uma contenda municipal entre Recife e Olinda, ou seja, entre o credor urbano e o devedor rural.

Olinda era a principal cidade de Pernambuco e sediava as principais instituições locais. Lá, os senhores-de-engenho tinham suas casas. Por outro lado, o porto de Recife, a poucos quilômetros de distância, era o principal local de embarque das exportações de açúcar da capitania. Durante a ocupação holandesa, o porto de Recife cresceu e tornou-se cada vez mais importante. Seus habitantes eram ricos comerciantes portugueses, desprezados pela oligarquia de Olinda, que os chamava depreciativamente de «mascates».

A tensão entre os comerciantes e os senhores-de-engenho chegou a seu ponto mais alto no momento em que o governador da capitania passou a morar em Recife. A situação piorou ainda mais quando Recife foi elevada à categoria de vila, em 1709. Isso significava que Re- 
cife não precisava submeter-se à autoridade da Câmara de Olinda.

Em 1710 um grupo de sediciosos tentou assassinar o governador, que fugiu para a Bahia. Enquanto isso, os senhores-de-engenho conseguem mobilizar as milícias rurais e o terço de Olinda contra Recife. A situação permanece tensa na capitania até a chegada do novo governador [...], em 1711. Trazia ele ordens para prender os chefes da sedição, reprimir os revoltosos e enviá-los a Lisboa.

Onze suspeitos foram embarcados para Lisboa em outubro de 1713. Em novembro começa a repressão ao movimento no interior. Mais de 70 pessoas foram presas e seus bens sequestrados. Quase todos os presos enviados a Lisboa morreram na prisão do Limoeiro. Apenas quatro recuperaram a liberdade. Os magistrados envolvidos com os rebeldes foram condenados ao ostracismo e nomeados para cargos em lugares remotos. (Lopes e Mota, 2008: 185-186)

Outra narrativa histórica, Brasil. Uma biografia (2015), de Lilia M. Schwarcz e Heloisa M. Starling, relata mais ou menos os mesmos fatos, com diferença de ênfase, mas dá destaque a um aspecto não referido na fonte precedente. Todas as revoltas professavam lealdade ao rei, contestavam o poder local, «exceto uma: a de 1710, em Pernambuco, responsável por introduzir uma nova tópica no padrão até então característico das sublevações coloniais e pôr em questão a autoridade da Coroa» (Schwarcz e Starling, 2015: 141). É descabido supor que Alencar, homem do século XIX, se alinhasse, conscientemente, com esta ou aquela interpretação. No entanto, nós, leitores de hoje, podemos notar que, tendo tantas revoltas à disposição em tempo histórico relativamente curto, Alencar escolheu aquela em que os historiadores nossos contemporâneos apreendem potencial independentista, republicano. Cabe lembrar circunstância biográfica em geral evocada pelos estudiosos: Alencar cursou o terceiro ano de Direito em Olinda (1848), portanto conhecia não só a história como o espaço, especialmente considerando a singularidade do trânsito entre Olinda e Recife, dado relevante no enredo do romance. Entretanto, sabemos que, se por um lado, Alencar é feliz ao retratar sua terra natal, a exemplo do que faz em Iracema e $O$ sertanejo, nem por isso se constrangia com o desconhecimento do espaço ficcionalizado, a exemplo de 0 gaúcho. Gostaria ainda de chamar a atenção para o fato de, em ambas as narrativas históricas, ficar evidente que não se trata de capítulo da história que se preste facilmente a uma abordagem leve, o episódio oferece conteúdo dramático de alta voltagem. Alencar faz outra opção.

No volume não há indicação do gênero literário «romance», e sim o subtítulo «Crônica dos tempos coloniais». Vale lembrar que a crônica, à época, em acepção herdada do medievo, fica entre os anais, isto é, registro de sequência de fatos e datas, e a historiografia. Tal crônica, nos diz o autor na «Advertência», foi descoberta por acaso. Cito os parágrafos iniciais:

\footnotetext{
Alinhavou-se esta crônica sobre uma pape-
} lada velha, descoberta de modo bem estúrdio. 
la proceder-se à eleição primária em uma paróquia dos subúrbios do Recife. Desde a véspera que o rábula político do lugar tinha arranjado a cousa a bico de pena e conforme a senha; mas era preciso dar representação e mostra oficial da farsa para embaçar uns escrúpulos ridículos do presidente calouro.

Para esse fim um grupo de governistas, com o competente destacamento policial, acampou na Matriz, onde a oposição, que tivera o cuidado de meter-se nas encóspias, não apareceu. $\mathrm{Na}$ ocasião de começar a encamisada, deu-se por falta da urna de que ninguém se lembrara. Felizmente lá desencavaram no fundo do armário da sacristia um cofre ou arca de jacarandá, que devia ter servido, no tempo de El-Rei Nosso Senhor, para guardar os pelouros da vereança.

Havia dentro da tal arca três antigualhas, dignas de uma memória do Instituto Histórico. Eram: uma cabeleira de rabicho que naturalmente pertenceu ao último juiz do povo; uma liga de belbute com atacadores de prata em forma de corações, adereço casquilho de alguma Egéria dos tempos coloniais; e finalmente um grosso rolo de escrita enleado com um cadarço de Lamego.

Sem o menor respeito atiraram essas preciosas relíquias a um canto, onde as descobriu dois dias depois o sacristão da freguesia. (Alencar, s. d.: 5)

Temos, já na «Advertência», um enredo, não muito menos mirabolante do que o enredo da narrativa propriamente. Segue-se a informação de que por não ter sido atendido em suas pretensões, o sacristão envia esse material a um jornalista de oposição. Este, por sua vez, pretendendo minar os vencedores, redige furibundo artigo, apresentando o conteúdo da arca como prova do bacanal que teria ocorrido nas eleições locais. $O$ dito rabicho é atribuído a personalidade política do momento e a dita «liga de belbute» é lançada na conta de dama benemérita da sociedade, enquanto os papéis são identificados como as cédulas de votação rasgadas. A pretensão é provar a ilicitude das eleições e lançar o descrédito sobre os políticos da situação. É claro que acusações e defesas provocam ebulição no cenário político local, com repercussões na corte, alcançando o ministério do Império. Nesta altura aparece o eu autoral, ou melhor, do narrador. 0 tal jornalista pernambucano teria ido à corte e visitado o colega jornalista - eu do discurso - para que preparasse «um artigo de minha lavra, confiando-me para este fim o pacote onde estava o corpo de delito do grande escândalo» (Alencar, s. d.: 9). O pacote acaba atirado a um canto, por vários meses, durante os quais acontecem reviravoltas na política nacional, incluindo a câmara e o próprio ministério. As razões para cada movimento político obedecem sempre a mesma lógica: uma picuinha, iniciada por uma figura secundária, toma vulto e provoca queda de uns e ascensão de outros, sempre dentro da mesma casta, enquanto as justificativas que aparecem oficialmente são de outra ordem. O jornalista pernambucano, tendo sido agraciado com alguns favores, muda de lado, bem como o sacristão também 
recebe benefícios. Ao enredo da «Advertência» não falta sequer diálogo:

A câmara fora dissolvida. 0 jovem escritor tinha sido eleito deputado, e estava com assento na câmara. Um domingo por manhã recebi sua visita [trata-se do jornalista que entregara o embrulho].

Trouxe-me à memória o embrulho que ainda atravancava uma gaveta de minha papeleira. Sem advertir que fazia um epigrama ao Cícero pernambucano, perguntei-lhe:

- Que destino devo dar aos objetos que V. Exa. me confiou? Quer que os envie à sua residência?

- Oh! não vale a pena! respondeu com um rubor de primeira legislatura. A mudança, que se operou na política, tirou a estes objetos sua importância.

- Ao sair encontrou-se a visita com um indivíduo esguio, que subia a escada. 0 feto ministerial não se dignou abaixar o augusto e digníssimo olhar para a zumbaia do desconhecido, cujo ar beguino cheirava de longe a morrão de igreja.

Quem havia de ser o sujeito?

O marreco do sacristão, que já foi encaixado na Guarda Nacional vinha à corte pretender um empregozinho para viver. [...]

Mas nunca um tagarela caiu-me tão a propósito do céu como aquele.

- Sr. Beltrão, meus pequenos serviços estão à sua disposição; mas não tenho valimento. É bom que procure os deputados de sua província.

- Qual, sr. doutor. São uns ingratos; já estou escarmentado deles. Não viu este que saía quando entrei? Depois que se encarrapitou, faz que não conhece a gente. Não gosto de falar... Mas se não fosse eu, ele não estaria hoje - senhor deputado!

- Trabalhou a favor de sua candidatura?

- O sacristão olhou-me com um sublime gesto de modéstia:

- Fui eu que derrubei o ministério passado.

- Ah!...

O Sr. Beltrão tinha em um saguão ministerial travado conhecimento com o correio do ex-presidente do conselho, que the referiu a verdade verdadeira a respeito da queda do último ministério.

- Ora, concluiu ele; quem meteu o capitão-mor na dança fui eu.

- Então ele não perdeu a cabeleira na igreja?

- Qual cabeleira, sr. doutor. Aqueles cacarecos velhos estavam escondidos numa caixa do defunto vigário, que a tinha metido no armário da sacristia. Eu é que arranjei a tramóia com o escrivão.

- Pois Sr. Beltrão, já vejo que há de ser bem sucedido em sua pretensão. Um homem de seu talento deve ir longe. (Alencar, s. d.:11-12)

Atente-se para o jogo entre o que acontece, a «verdade verdadeira», e como os efeitos ganham outra versão.

Despertada a curiosidade, o narrador abre a caixa:

O rolo de papel, que o escritor pernambucano, jurando na palavra do escrivão, qualificara de maço de cédulas e como tal fora visto por várias pessoas; era nada menos do que um tesouro. Era o manuscrito de uma crônica inédita da Guerra dos Mascates. Devorei o cartapácio e 
desde logo fiz tenção de o tirar a lume, espanando-lhe de leve as roupagens do estilo, que me pareceram um tanto poentas. (Alencar, s. d.:13)

Portanto, o que nos é dado a ler não é a transcrição exata do «cartapácio». Alencar, como os políticos que justificam suas decisões com razões distorcidas, também adota o jogo de cara e coroa, o que se vê e o que se esconde: sob a justificativa de tornar mais legível, para o leitor do século XIX, a redação que seria do século XVIII, inclui suas observações, suas análises. Antecipa acusações que pesarão sobre ele, ou talvez sobretudo dê a pista para seus contemporâneos:

Esta advertência, bem se vê que era imprescindível, para evitar certos comentos. Não faltariam malignos que julgassem ter sido esta crônica inventada à feição e sabor dos tempos de agora, como quem enxerta borbulha nova em tronco seco; não quanto à trama da ação, que versa de amores, mas no tocante às cousas da governança da capitania.

Pois não lograrão seu intento; que o público aí fica munido do documento preciso para julgar da autenticidade desta verídica história.

Se os tempos volvem como as vistas de uma marmota, e as figurinhas cá do presépio da terra entram para saírem, com os mesmos engonços e geringonças, embora metidas em trajos diferentes; disso não tem culpa o cronista. Lá se avenham com o mundo, que é o titereiro-mor de tais bonecos. (Alencar, s. d.:13)

Ou seja, se leem sua narrativa como crítica à política do Império, não é porque o autor travestiu a contemporaneidade com datas e nomes do passado, é porque a história se repete! Ver a possibilidade de Guerra dos mascates fazer crítica à situação política do momento como defeito, conforme se depreende de algumas leituras, é esquecer que uma das funções do romance histórico, das mais relevantes, é auxiliar no entendimento da contemporaneidade.

Finalmente, quero destacar que, no último parágrafo, anunciando que esta é a primeira parte, portanto haverá uma segunda, Alencar dá outra pista, ao dizer que essa crônica «bem se pode chamar [...] comédia». A «Advertência» é concluída com a indicação «Tijuca, dezembro de 1870». A data registrada no final do tomo é «12 de maio de 1873» (p. 144), ano da publicação do primeiro tomo.

Vale notar que, além de inscrever a obra no recurso tradicional do romance histórico de criar uma fonte, atribuindo a narrativa a antigo manuscrito - expediente de longo curso nessa modalidade romanesca - Alencar antecipa um dos temas do romance: a crítica à política de qualquer tempo, em que fatos decisivos nos caminhos da comunidade, quando não da nação toda, têm ponto de partida aleatório, acidental, originados por ações de indivíduos sem qualquer expressão, sem lugar de destaque na cena social e política. Os termos «sátira», usado por Valéria de Marco, e «comédia», usado por Alencar, serão as chaves de leitura aqui ativadas. Dispensar trato jocoso a eventos históricos, ainda que não seja uma inovação - 
lá nos primórdios está Cervantes dando essa lição - é traço bastante frequente na ficção do final do século XX. Não costumamos atentar para essa antecipação em Alencar.

A «segunda parte», publicada no ano seguinte, também traz «Advertência», datada da «Corte, 1 de junho de 1974». Esta é muito mais breve, mas também faz parte de um enredo, este referencial. $O$ autor disserta sobre o modo de figuração da ficção histórica, uma vez que «houve muito quem teimasse em ver personagens contemporâneos disfarçados nessas figuras do século passado» (Alencar, s. d.: 147). Quer dizer, aquela isca lançada no final da «Advertência» do volume anterior foi pega. A Guerra dos mascates foi lido como roman à clé, leitura que persiste na maioria das histórias da literatura, no sentido de desqualificar a obra, insistindo-se nas circunstâncias biográficas, momento de maior rusga com o Imperador. 0 polemista que bem conhecemos dá resposta, mas admite: «Ora, o autor não pretende certamente defender-se do pecado de uma ou outra alusão, que the corre às vezes sem querer dos bicos da pena. Mas essas demasias, não as tem senão sobre a política, que é já de si um longo e interminável epigrama» (Alencar, s. d.: 147).

Quanto ao enredo romanesco propriamente dito, a narrativa é aberta com o registro da data - 1 de outubro de 1710 - seguido de informações sobre o clima e o espaço, constituindo o cenário em cujo centro está a casa de um comerciante, no Recife. Logo entram as personagens, uma menina, Marta, que chupa cana, à janela, da qual se aproxima um rapazinho, Nuno. Os apetrechos que este porta indicam a condição de vendedor de miudezas. O casal, que hoje diríamos de adolescentes, fica num jogo entre sedução e brincadeira, cena que é bruscamente interrompida pela chegada de «brilhante cavalgada». Trata-se do governador da capitania, Sebastião de Castro Caldas, e seus acompanhantes. Um ajudante, com patente de capitão, ao perceber que o governador fica tocado pela visão da moça, mas logo se mostra incomodado ao notar que ela tem companhia, promove imediata perseguição ao rapaz, que empreende desabusada fuga, submetendo o capitão ao ridículo. É o quadro de uma comédia, à moda de Martins Pena. Esse será o tom dominante na narrativa: pares amorosos sem aura, «nobreza da terra» cuja seriedade é caricata, pretensões dos novos ricos, os comerciantes, pusilanimidade daqueles que estão entre uma classe e outra, tentando servir a dois senhores. Vale notar que não se trata exatamente de uma oposição «portugueses versus brasileiros» uma vez que, nos tempos coloniais, nascidos na metrópole ou na colônia, todos eram cidadãos da mesma nação. A disputa é de outra ordem. Como bem registram Adriana Lopes e Carlos Guilherme Mota na obra acima citada, o desentendimento se deu entre «comerciantes da Metrópole», os ditos «mascates», e «produtores luso-brasileiros». 
A ação segue com Nuno, que é, assim como sua amada, filho de comerciante, encontrando-se com dois conhecidos, um que escreve versos, Lisardo, outro que é «fuinha de cartório» (Alencar, s. d.: 45), ou seja, copista que trabalha para o tabelião, Cosme. Essas três figuras, pouco relevantes socialmente, têm participação intensa no desenvolvimento da ação. Trata-se, em princípio, de um traço do romance histórico scottiano, mas a ação destes três não é acidental, como preconiza Lukács, antes decisiva na ação romanesca. 0 trio, frequentando os dois espaços geográficos e sociais, faz a ponte entre os moradores de Olinda e os do Recife, ponte que não é de ligação, e sim de conflito. Os primeiros são pernambucanos tradicionais, portanto também súditos portugueses, cujo cabedal está calcado na tradição de defesa do território, que já é coisa do passado, e no patrimônio constituído pelo cultivo da cana-de-açúcar, nesse momento em decadência. Os segundos são os comerciantes, pejorativamente chamados mascates, vindos de Portugal para fazer fortuna na colônia. Estabeleceram-se no porto e suas proximidades, seja para facilitar suas atividades, seja porque essa terra considerada insalubre foi a encontrada. No tempo em que se situa a ação, o poder econômico está mudando de mãos, portanto disputa-se o poder político. Como se viu nas fontes históricas, Recife reivindica sua própria câmara, enquanto Olinda pretende manter a hegemonia.
Na criação do romancista, a disputa política assume ares de farsa. Nuno não quer seguir as atividades do pai. Seu ideal está nas armas, onde vê possibilidade de satisfazer sua ousadia e afoiteza. Ao perceber que a traquinagem desafiando o capitão vai resultar em mandarem-no estudar em Portugal, bandeia-se, por artimanhas sempre de farsa, para o lado dos pernambucanos. Quem o acolhe é uma velha dama solteira, D. Severa. Essa dupla responde pelo eco do tempo das cruzadas, ou melhor, pelo traço quixotesco. Ela vive lendo novelas de cavalaria e lamentando que já não se viva naqueles moldes, quando os cavaleiros se submetiam a qualquer sacrifício por suas amadas, e as mulheres eram ouvidas e tinham suas opiniões respeitadas, inclusive nos assuntos de guerra. Para D. Severa, cuja aparência física é de uma bruxa nariguda que posa de ninfa, o passado, além de idealizado, é chapado. 0 mundo, calcado em suas leituras do Palmeirim, é criado como se fosse o de sua própria juventude. As fantasias dessas duas personagens fazem com que, recuperando antigas armaduras e armas de guerra jogadas em um quarto de despejo, ela mesma se arme como cavaleiro e, trazendo o mascatinho como pagem, desafie o governador. Em outra ocasião, já próxima do desfecho, convocam quantos desocupados encontram e, a troco de algumas moedas, montam uma tropa travestida com apetrechos anacrônicos encontrados no mesmo depósito, cujo intuito era vencer de vez as pretensões do povo do Recife. Algumas 
das cenas mais hilariantes são promovidas por esses dois. Sua presença é também oportunidade para apresentar as famílias olindenses, suas casas decoradas de modo a evidenciar sua antiga nobreza e seus hábitos de vida em clã, composto por indivíduos que são cúmplices em alguns assuntos, e concorrentes entre si em alguns aspectos.

O poeta Lisardo, segunda personagem do trio, muito pobre, é recebido nos serões em Olinda, graças à tradição da nobreza de, em arremedo de mecenato, conceder acolhida aos artistas, a troco de algumas declamações. Mas seu coração está no outro núcleo, uma vez que é apaixonada pela irmã de Nuno. A certa altura, é obrigado a escrever uma quadra desaforada provocando os do Recife:

Todo mascate é patife,

Labrego, cara de Judas;

$E$ as mulheres do Recife

Têm as pernas cabeludas.

(Alencar, s. d. : 242)

Os dois primeiros versos não têm maior repercussão, mas os dois últimos fazem com que as mulheres, especialmente D. Rufina, mãe da mocinha da abertura da narrativa, sintam-se particularmente ofendidas e resolvam responder à altura. 0 mesmo poeta é convocado, sob ameaças, para redigir a resposta, que resulta em uma quintilha:

Escorridas como um fuso,

As damas de Olinda são;
Por fora aquele esparrame,

Por dentro só armação

De pano, d'osso e de arame.

(Alencar, s. d.: 247)

Não é preciso dizer que, obrigado a servir a dois senhores, ou melhor, duas senhoras, o poeta se dá muito mal, e morreria de inanição, não fosse a ação do amigo Nuno, também em cena hilariante. Não é possível referir todas as cenas deste teor, mas essa troca de insultos merece atenção. Antes disso, para completar as informações sobre o trio, vale dizer que o leva-e-traz dos versos e de outras intrigas, sempre disfarçado, é Cosme. Se o poeta serve os dois lados por necessidade, o escrevente imiscui-se nos dois espaços por interesse, na expectativa de qual lado poderá alcançar maiores benefícios. Quanto à importância dos versos na narrativa, o capítulo que narra esses sucessos é intitulado «Descobre-se o casus belli com que não atinaram os cronistas da Guerra dos Mascates». Se o leitor não der a devida atenção a esse título, no último parágrafo do capítulo o narrador reforça: «Mas a história da perna cabeluda posta em versos tinha abespinhado a venerável matrona [D. Rufina], que desde esse momento não respirou senão vingança, e tanto fez que terminou por desencadear a guerra dos mascates, apesar de todas as manhas de D. Sebastião» (Alencar, s. d.: 247). Aí reside um dos pontos em que há o fio que liga o romance à produção nossa contemporânea: além da narração da história, há essa intervenção, criando uma história alternativa. 
Nessa mesma linha, ainda um dado do enredo que serve de reforço ao argumento: o atentado sofrido pelo governador, registrado nos anais históricos, no romance é um tiro de sal, disparado por ordem da mesma matrona, com o intuito de chamar o governador aos brios, diante da pressão dos olindenses. As referidas «manhas de D. Sebastião» ainda vão merecer atenção, mas antes convém fechar o quadro amoroso, que tem mais um par, este sim no modelo romântico. Citações isoladas referentes a estas duas personagens poderiam desautorizar a leitura aqui proposta. No entanto, vale lembrar que é um entre os três pares amorosos e essa relação não move o enredo.

O espaço se desloca para Olinda no capítulo $x$ da Primeira Parte. A geografia da cidade é apreendida pelos olhos do Alencar que se conhece. Um panorama de rara beleza merece descrição tipicamente alencariana. A câmara narrativa aproxima-se de uma casa e a lente focaliza duas mulheres que se ocupam de trabalhos manuais, «uma já revelhusca; a outra, moça e formosa», tia e sobrinha (Alencar, s. d. :93). A «revelhusca» é a já referida D. Severa. Quanto à condição da moça, Leonor, em suas próprias palavras:

Pois, tia, não me hei de queixar de minha sorte, que me fez donzela e casada, sem que o seja nem uma, nem outra? Não me pertenço a mim, que sou de quem me disse o coração; não me pertenço ao meu marido, que dele me tem separada. Ah! soubera eu do que me esperava, que não teria consentido! Afinal de contas ele é meu esposo e eu devia acompanhá-lo [...]. (Alencar, s. d.: 94)

Páginas adiante um flashback dá conta de como se chegou a essa situação. Leonor e Vital Rabelo são perdidamente apaixonados, ainda que praticamente só se avistem de longe, no padrão romântico. $O$ problema é que ela é da melhor família olindense, enquanto ele é filho de comerciante do Recife. Não bastasse esse entrave de castas, o pai dele tinha comprado as terras que o pai dela perdera em mesas de jogo. Evidentemente, a família tem todas as razões para se opor à união. No entanto, o governador, nas suas habituais práticas ambíguas travestidas de tentativas conciliatórias, gestiona junto à família. Esta, que não por acaso está entre aqueles que detêm o poder por tanto tempo, sabe o momento de perder um ponto para ganhar o jogo. Prepara-se uma armadilha. Realizado o casamento, na hora da partida dos noivos, anuncia-se a decisão familiar: o novo casal deve ficar residindo em Olinda, há aposentos preparados na casa da família. Seria um recurso para, com o tempo, fazer com que o noivo se bandeasse para o lado dos olindenses. Este, filho de comerciante, mas que construíra para si um código de conduta que o habilitava à mais alta nobreza moral, não se submete. Os artifícios que os apaixonados usam para se avistar, no longo período de separação, são folhetinescos. Não falta nem o bilhete escrito com sangue, em um lenço, na impossibilidade de acesso a papel e tinta. 
No entanto, a cunha irônica, marcada no adjetivo, aparece no título do capítulo, o XI da Primeira Parte: «O primeiro sangue derramado na famosa guerra dos mascates» (Alencar, s. d.: 98).

O episódio histórico que dá título ao romance não está compreendido no tempo narrativo, programaticamente, como revela o título do capítulo derradeiro: «No qual se acaba a crônica justamente quando ia começar a guerra dos mascates». A edição princeps traz, na página de rosto, a indicação «(O Prologo)» (Alencar, 1873). Os últimos sucessos ficcionais ocorrem em 17 de outubro, portanto o tempo narrativo é de praticamente uma quinzena. A atenção do romancista está voltada para os antecedentes, para as causas do conflito. Vale lembrar que na narração sobre como o manuscrito veio parar nas mãos do autor também há detalhada descrição dos antecedentes, e, sobretudo, o jogo entre as justificativas oficiais e as razões particulares. Pode-se entender o discurso das «Advertências»e, especialmente, as páginas identificadas como «Nota referente à $1 .^{a}$ edição» como uma poética do romance, associada a uma concepção de história, concepção que não é romântica e nem positivista. Alencar não privilegia os fatos nem as causas oficiais. Tenta entender o ser humano e as ações ditadas por suas fraquezas, que resultam por vezes em escaramuças, por vezes em reviravoltas históricas. Há uma enorme quantidade de personagens, que não cabe referir neste espaço, inclusive uma personagem secundária, praticamente sem participação, cujas manifestações autorizam a apontá-lo, como fizeram muitos críticos, como alter-ego do autor. Detectar aí manifestação de autoficção seria abuso, mas é preciso reconhecer que a presença do autor no plano ficcional é um dos procedimentos da ficção da atualidade.

Na reescritura da história promovida pelo romancista, a Guerra dos Mascates foi desencadeada por uma disputa entre mulheres dos dois grupos rivais, ofendidas por referências a suas características físicas. Inclusive o atentado ao governador é não só iniciativa feminina como um logro. Afinal, tiros de sal não matam, a prática serve apenas para espantar, usada sobretudo para cachorros. No entanto, a narrativa oferece elementos para outra leitura. Se não nos deixamos embair pelo autor, que na «Advertência» da Primeira Parte afirma que a «trama da ação [...] versa de amores», e atentamos para a continuação do mesmo período, que refere «o tocante às coisas da governança da capitania», vale retornarmos à figura de D. Sebastião de Castro Caldas, em leitura que o promova a protagonista, alçando-se a questão histórica ao primeiro plano da narrativa. Essa proposta não trai as intenções autorais, talvez antes as apreendam, dada a quantia e a qualidade dos elementos constantes no romance focalizando o governador.

Na cena de abertura, já referida, a figura é descrita na dimensão física e psicológica. Nessa altura pode-se objetar que esse tipo de apresentação é vezo de Alencar. No entanto, 
o narrador não perde oportunidade de acentuar o jogo entre o parecer - dirigente imparcial, pouco atento às práticas palacianas e às cortesias dos cidadãos - e o ser - indivíduo que não toma partido para não se indispor com nenhum dos lados, simulando atender a ambos, aproveitando as benesses que cada um pode lhe oferecer. Se o leitor não apreende as pistas dispersas, um capítulo específico sustenta essa leitura. O capítulo II da Segunda Parte, intitulado «Um capítulo de história que parece ter sido escrito para o romance», é longo, em registro discursivo diferenciado, revelando cuidadosa pesquisa histórica, despido da ironia que perpassa os demais capítulos. Conclui com a informação sobre a determinação da «carta régia de 19 de novembro de 1709» (Alencar, s. d.: 170) criando a vila de Recife: «Mas apesar de todas estas razões políticas, Sebastião de Castro descobriria alguma conveniência para adiar a criação da vila, se não estivesse nisso empenhado o seu amor próprio» (Alencar, s. d.: 171). Ou seja, para Alencar, a guerra poderia não ter acontecido, se o governador não fosse quem era, se fosse capaz de se conduzir de outra forma. Nessa leitura, em que a figura histórica central é alçada à condição de protagonista, também uma subversão ao romance histórico tradicional, é possível subverter também o título do capítulo. «Um capítulo de história que parece ter sido escrito para romance» pode ser lido como «Um romance que foi escrito como capítulo da história».
Com essa proposta pretende-se provocar também alguma subversão na História da Literatura, incluindo o romance Guerra dos mascates na trajetória do romance histórico brasileiro, não como protótipo do romance histórico romântico, nem como revivescência dos primórdios do romance histórico, nem como precursor do romance contemporâneo, mas como obra que ocupa posição singular, questionando o modelo vigente à sua época, seja da disciplina História, seja do romance histórico. Nesse questionamento, antecipa práticas que viriam a ser marcas da retomada e renovação da ficção histórica das derradeiras décadas do século XX. Evidentemente, tal leitura só pode ser feita em retrospectiva, depois de se conhecer a produção de hoje.

A intenção desta leitura não é discutir as motivações da obra, mas colocar em relevo a singularidade desse romance histórico, inclusive em relação aos demais títulos do autor, apreendendo os fios que lança em direção ao passado, mergulhados nas raízes do romance histórico, as novelas de cavalaria, e os fios que projeta para o futuro, o romance histórico nosso contemporâneo. Não se está propondo que Guerra dos mascates seja um novo romance histórico, nos termos que a crítica usou essa expressão ou suas variações a partir das últimas décadas do século passado, ou que Alencar seja um pós-moderno avant la lettre, bem como não se está propondo que Guerra dos Mascates seja uma revivescência das origens do romance histórico, resultante 
de atitude passadista. Também não se nega a possibilidade de as circunstâncias biográficas terem influenciado ou mesmo determinado a escolha da modalidade discursiva. O intuito é resgatar esse título, incluindo-o no percurso do romance histórico brasileiro, uma vez que a exclusão não parece determinada pela fatura romanesca, em si, e sim pela fuga ao modelo então dominante e mesmo ao padrão alencariano, duas linhas de expectativa frustradas pela leitura do romance. 0 nacionalismo, linha de força do Romantismo, no caso brasileiro alimentado vivamente pelo próprio Alencar, ainda era ufanista, não tinha condições de reconhecer a crítica contida na comédia. As histórias da literatura produzidas no século XX, orientadas pelo princípio de tendências dominantes, não se deram ao trabalho de atentar para obra que contradizia o modelo, mas nem por isso é falho como realização romanesca.

\section{Bibliografia}

ALENCAR, J. (s. d. [1872]). Benção paterna. Em: Sonhos d'ouro. Ediouro. Rio de Janeiro;

ALENCAR, J. (1990 [1873]). Como e porque sou romancista. Pontes. São Paulo;

ALENCAR, J. (1873-1874). Guerra dos mascates: Chronica dos tempos coloniaes. B. L. Garnier. Rio de Janeiro;

ALENCAR, J. (s. d.). Guerra dos mascates. (2. a ed.). Melhoramentos. Rio de Janeiro;

AMORA, A.S. (1973 [1967]). O romantismo. (4. ${ }^{a}$ ed.). Cultrix. São Paulo;

BOSI, A. (1990 [1973]). História concisa da literatura brasileira. (2. ${ }^{a}$ ed.). Cultrix. São Paulo; CANDIDO, A. (1975 [1957]). Formação da literatura brasileira: Momentos decisivos. (5. ${ }^{a}$ ed.). Itatiaia/ Ed. da USP. Belo Horizonte/São Paulo; LOPEZ,A. e MOTA, C.G. (2008). História do Brasil: Uma interpretação. Editora Senac. São Paulo; MARCO, V. (1993). A perda das ilusões: O romance histórico de José de Alencar. Editora da UNICAMP. Campinas;

SCHWARCZ, L.M. e STARLING, H.M. (2015). Brasil: Uma biografia. Companhia das Letras. São Paulo. 